\title{
Changes in maternal body composition and metabolism of dairy goats during pregnancy
}

\author{
Douglas de Souza Castagnino', Carla Joice Härter ${ }^{1}$, Astrid Rivera Rivera ${ }^{1}$, Lisiane Dorneles de \\ Lima $^{2}$, Herymá Giovane de Oliveira Silva ${ }^{1}$, Bruno Biagioli ${ }^{1}$, Kleber Tomás de Resende ${ }^{1}$, Izabelle \\ Auxiliadora Molina de Almeida Teixeira ${ }^{1}$
}

\author{
${ }^{1}$ Universidade Estadual Paulista, Departamento de Zootecnia, Jaboticabal, SP, Brasil. \\ ${ }^{2}$ Empresa Brasileira de Pesquisa Agropecuária, Embrapa Caprinos e Ovinos, Sobral, CE, Brasil.
}

\begin{abstract}
The objective of this study was to evaluate the mobilization of nutrients in goats of different gestation types and pregnancy stages. Forty-four Saanen and Oberhasli goats were studied. The goats of each breed and gestation type (single or twin) were slaughtered at different gestational ages $(80,110$, and 140 days of pregnancy), forming a completely randomized design in a $2 \times 3 \times 2$ factorial arrangement (two breeds, three gestational ages, and two types of pregnancy). The slaughter procedure involved separating the empty body, mammary glands, uterus with membranes and fetal fluid, and fetus(es). For the females slaughtered at 140 days of pregnancy, blood was collected to analyze metabolites and hormones every 15 days during gestation. The dry matter (DM) intake was lower in goats with twin pregnancies. The relative daily retention rate of the nutrients in the body was positive at 100 days of pregnancy but became negative at 140 days $\left(-0.18 \pm 0.25 \mathrm{~g} \mathrm{DM} \mathrm{kg}^{-1}\right.$ of maternal body d $\left.{ }^{-1}\right)$ and did not differ with breed or number of fetuses. Fetal growth in twin pregnancies was $66 \%$ higher than in single pregnancies. The highest levels of $\beta$-hydroxybutyrate and non-esterified fatty acids were observed beginning at 100 days of gestation. Serum total protein and albumin levels decreased after 125 days of gestation. Serum urea levels were reduced after 80 days of gestation. Plasma 17ß-estradiol levels increased with the advance of pregnancy, and IGF-1 was highest between 60 and 80 days of gestation. The maternal metabolism throughout pregnancy does not vary with the type of pregnancy, and pregnant goats need greater nutritional intake during the final third of the gestational period regardless of the breed or type of pregnancy.
\end{abstract}

Key Words: energy metabolism, hormone profile, metabolic and nutritional profile, pregnancy outcomes, type of pregnancy

\section{Introduction}

Profound metabolic changes take place in pregnant females, and the physiological mechanisms involved in these changes have primarily been studied for the last six weeks of gestation because this is the period during which approximately $70 \%$ of fetal growth and the majority of the development of the glandular and mammary tissues occur, contributing to an increase in energy requirements (Conway et al., 1996; NRC, 2007). At the same time, there is a decrease in dry matter intake caused by the compression of the rumen by the fetus and elevated estrogen concentration (Forbes, 2007).

This scenario may lead to increased efficiency in nutrient use in the final stage of pregnancy (Bauman and Currie, 1980; Bonnet et al., 2002; Duarte et al., 2013), which may not be sufficient to compensate for the decreased dry matter

Received September 22, 2014 and accepted February 6, 2015

Corresponding author: harter.carla@gmail.com

http://dx.doi.org/10.1590/S1806-92902015000300003

Copyright (C) 2015 Sociedade Brasileira de Zootecnia. This is an Open Access article distributed under the terms of the Creative Commons Attribution Non-Commercial License, which permits unrestricted non-commercial use, distribution, and reproduction in any medium, provided the original work is properly cited. intake, so the pregnant goat may have a negative energy balance (Bell, 1995). As a consequence, the female starts to mobilize body reserves to meet its energy requirements as well as use alternative substrates to produce propionate for glucose synthesis in the liver (Prezotto et al., 2013). Although the negative energy balance has already been explored in studies of dairy cows, there are currently no studies addressing this physiological process in the goat, which may suffer from an even more marked energy deficit due to its high prolificacy and high incidence of twin births (Amoah et al., 1996).

Moreover, no information exists in the literature to indicate whether goat breeds with the same productive aptitude utilize the same metabolic mechanisms under a negative energy balance. Studies show that there are differences in productive and reproductive traits among dairy goat breeds; Saanen animals show higher precocity, milk yield and lactation longevity, whereas Oberhasli goats display a higher concentration of milk protein and fat (Boichard et al., 1989). These differences among genotypes may indicate different physiological adaptation mechanisms under the same nutritional conditions, especially during pregnancy (Silanikove, 2000; Macciotta et al., 2011). 
Another noteworthy factor is that many of the studies focus on the final stage of pregnancy or on the transition period (end of gestation and beginning of lactation), so it is possible that the adaptive mechanisms are activated before the final weeks, especially in twin pregnancies (Bauman and Currie, 1980; Bell, 1995). Therefore, it is important to understand the mobilization of nutrients in the female body and their transfer to other products of gestation. Thus, the objective of this study was to evaluate changes in the maternal body and the metabolic profiles of Saanen and Oberhasli goats with single or twin pregnancies over the entire gestational period.

\section{Material and Methods}

Forty-four non-pregnant and non-lactating multiparous goats, 22 of the Saanen breed and 22 of the Oberhasli breed, with an initial average body weight of $49.5 \pm 7.6 \mathrm{~kg}$ and an average body condition score of 2.75 , were studied. The animals were stabled in individual stalls $(1.2 \mathrm{~m} \times 0.5 \mathrm{~m})$ in a shed that was protected from wind and rain by a metal roof. All of the procedures adopted in this experiment were approved by the Committee of Ethics in Animal Use of UNESP, protocol no. 026167-07.

After showing estrus (natural or induced), the goats were naturally mounted by a sire of the same breed. During the seasonal estrous period, the females were subjected to a heat-induction protocol using a hormone treatment recommended by Westhuysen (1979) and Ritar et al. (1984). Thirty-five days after mounting, an ultrasound examination was performed to diagnose pregnancy and count the number of fetuses.

The diet (Table 1), formulated according to the NRC (2007), was supplied ad libitum, twice daily, at $08.00 \mathrm{~h}(60 \%$ of the daily total) and $17.00 \mathrm{~h}$ (40\% of the daily total). The daily control of dry matter (DM) and nutrients was achieved by weighing the amount supplied and refused by the animals, and the amount to be supplied was adjusted to keep orts at $15 \%$ of the total supply. Animals had free access to water.

Eight animals (four of each breed) were initially slaughtered to estimate the body composition of nonpregnant and non-lactating goats.

After the diagnosis of pregnancy, the goats of each breed were divided into two groups according to pregnancy type (single or twin), and these groups were divided randomly according to the pregnancy ages for slaughter $(80,110$, and 140 days after mating).

For the animals randomly chosen for slaughter at 140 days, blood was collected at 1, 35, 50, 65, 80, 95, 110, 125, and 140 days of pregnancy to evaluate the variation in the concentrations of metabolites and hormones throughout pregnancy in the same animal and thereby reduce a source of variation among the animals.

Upon reaching the pre-defined dates for slaughter, goats were weighed without a prior period of feed deprivation, and this was considered the body weight at slaughter. After being stunned with a pneumatic gun, the goats were slaughtered by sectioning the jugular vein and carotid artery. The total amount of blood was collected, weighed, and stored for subsequent reincorporation into the animal body. After death was confirmed, the gravid uterus and mammary glands were removed. The gravid uterus was weighed and then separated into three parts: empty uterus (uterus, placenta, and placentomes), fetus(es), and fetal fluid, which were identified, weighed, and stored individually and then frozen in a cold chamber at $-15^{\circ} \mathrm{C}$.

The components of the digestive tract were weighed full and empty to determine empty body weight (EBW), which was calculated by subtracting the contents of the gastrointestinal tract, urinary bladder, and gallbladder from the body weight at slaughter. The maternal body (MB) was

Table 1 - Composition of the ingredients of the experimental diet

\begin{tabular}{|c|c|c|c|c|c|c|}
\hline \multirow{2}{*}{ Ingredients } & \multirow{2}{*}{$\mathrm{g} \mathrm{kg}^{-1}$ as fed } & \multirow{2}{*}{$\frac{\mathrm{DM}}{\mathrm{g} \mathrm{kg}^{-1}}$} & \multirow{2}{*}{$\frac{\mathrm{ME}^{1}}{\mathrm{MJ} \mathrm{kg}^{-1} \text { of } \mathrm{DM}}$} & $\mathrm{CP}$ & $\mathrm{EE}$ & $\mathrm{NDF}$ \\
\hline & & & & \multicolumn{3}{|c|}{$\mathrm{g} \mathrm{kg}^{-1}$ of DM } \\
\hline Tifton hay ${ }^{2}$ & 100.0 & 915.0 & 5.10 & 69.0 & 9.4 & 765.4 \\
\hline Corn plant hay ${ }^{3}$ & 349.4 & 916.0 & 9.10 & 46.0 & 17.0 & 537.5 \\
\hline Corn & 421.0 & 901.0 & 12.38 & 87.0 & 29.0 & 169.0 \\
\hline Soybean meal & 119.3 & 910.0 & 12.09 & 473.0 & 19.0 & 237.1 \\
\hline Premix & 3.7 & 990.0 & - & - & - & - \\
\hline Salt & 0.8 & 980.0 & - & - & - & - \\
\hline Limestone & 5.8 & 950.0 & - & - & - & - \\
\hline Total & 1000 & 908.0 & 10.33 & 116.0 & 21.0 & 377.8 \\
\hline
\end{tabular}

DM - dry matter; CP - crude protein; EE - ether extract; NDF - neutral detergent fiber.

${ }^{1} \mathrm{ME}-$ metabolizable energy $=[\mathrm{kg}$ TDN (according to Valadares Filho, 2002) $] \times[18.447 \mathrm{~kJ}] \times[0.82]$. The metabolizable energy of the corn plant hay was considered equal to the ME of the silage.

${ }^{2}$ Tifton 85 (Cynodon sp.)

${ }^{3}$ Whole corn plant without the roots that was cut when the grains reached $65 \%$ of the milk-line and then dried in the sun. 
calculated by subtracting the sum of the weights of the gravid uterus and mammary glands from the EBW.

Four structures were considered for the calculation of total retention and relative daily nutrient retention rates: maternal body, fetuses, mammary glands, and empty uterus + fetal fluid (UFF).

The DM (AOAC, 1990; method no. 930.15) and mineral matter (MM) (AOAC, 1990; method no. 942.05) contents were measured in the samples of the ingredients of the diets, orts, maternal body, empty uterus, fetal fluid, fetuses, and mammary glands. Ether extract (EE) was determined using a Sohxlet extractor for $5 \mathrm{~h}$, except for the samples of the maternal body and mammary glands, for which the extraction was performed for $8 \mathrm{~h}$ due to the high fat. The total nitrogen content of the samples was obtained by the Dumas combustion method using a LECO FP-528 LC analyzer following the procedure described by Etheridge et al. (1998) and then multiplied by 6.25 to obtain the total protein value. The neutral detergent fiber (NDF) contents of the ingredients were determined according to Robertson and Van Soest (1981) with the addition of thermostable $\alpha$-amylase. The energy content of the amniotic fluid was determined using a Parr 6300 bomb calorimeter. The energy contents of the maternal body, fetuses, mammary glands and empty uterus were determined by summing the energy contribution of protein (23.4304 $\mathrm{J} \mathrm{g}^{-1}$ protein) and ether extract (39.3296 J g ${ }^{-1}$ EE) according to ARC (1980). The ether extract values of the amniotic fluid were estimated by subtracting the protein energy contribution from the total energy content of this substance.

The retention of nutrients in the different structures (maternal body, fetuses, uterus and fetal fluid, and mammary gland) in the goats was calculated as the difference between the total amount of a certain nutrient on the day of slaughter and the total amount of the same nutrient at the onset of pregnancy.

The comparative slaughter method described by Lofgreen and Garret (1968) was used, and the composition at the beginning of pregnancy was estimated from the nonpregnant and non-lactating goats that were slaughtered at the onset of the experiment (4 Saanen and 4 Oberhasli). Regression equations were generated to estimate the total initial amounts of nutrients in the maternal body and in each component related to the pregnancy with the effect of breed taken into account when significant (Table 2).

The relative daily retention rate was calculated by equation (1):

Relative daily retention rate $=\mathrm{TR} \mathrm{W}^{-1} \mathrm{DP}^{-1}$

in which $\mathrm{TR}=$ total retention of $\mathrm{DM}$ or protein or $\mathrm{EE}(\mathrm{g})$ and/or energy $(\mathrm{kJ})$ in the maternal body in each pregnancy component; and $\mathrm{W}=$ average weight of the structure $(\mathrm{kg})$. For the animals slaughtered at 80 days of pregnancy, the average weight from 0 to 80 days was used; for those slaughtered at 110 days of gestation, the average weight between 0 and 110 days was used, and for the goats slaughtered at 140 days, the average weight from 0 to 140 days was used. Finally, DP = days of pregnancy $(80,110$, or 140 days).

Blood samples were collected by jugular venipuncture using Vacutainer ${ }^{\circledR}$ tubes without sodium heparin. The blood samples were placed in a refrigerated centrifuge at $4{ }^{\circ} \mathrm{C}$ for $15 \mathrm{~min}$ at $1,370 \times \mathrm{g}$ to separate the plasma and serum, which were stored separately in $15 \mathrm{~mL}$ Eppendorf tubes. The samples were frozen at $-20{ }^{\circ} \mathrm{C}$ until later analyses.

Table 2 - Intercept values (a), slope (b), probability values (P) and standard error of the mean (SEM) of the equations used to estimate the total nutrients in the maternal body (MBnp), mammary glands (MGnp) and uterus (Unp) according to the mass of the structure at the onset of pregnancy

\begin{tabular}{|c|c|c|c|c|c|c|c|c|c|c|}
\hline \multirow{2}{*}{ Variable $^{4}$} & \multirow{2}{*}{ Parameters } & \multicolumn{3}{|c|}{$\operatorname{MBnp}(\mathrm{g})^{1}$} & \multicolumn{3}{|c|}{$\operatorname{MGnp}(\mathrm{g})^{2}$} & \multicolumn{3}{|c|}{$\operatorname{Unp}(\mathrm{g})^{3}$} \\
\hline & & Value & SEM & P-value & Value & SEM & P-value & Value & SEM & P-value \\
\hline \multirow[b]{2}{*}{ DM (g) } & $\mathrm{a}$ & -7004 & 3055 & \multirow{2}{*}{$* *$} & -30.7 & 38.9 & \multirow{2}{*}{$*$} & 0.362 & 1.223 & \multirow{2}{*}{$* *$} \\
\hline & $\mathrm{b}$ & 0.648 & 0.063 & & 0.533 & 0.092 & & 0.176 & 0.009 & \\
\hline \multirow[b]{2}{*}{ Protein (g) } & $\mathrm{a}$ & 2146 & 1215 & \multirow[b]{2}{*}{$* *$} & 21.7 & 8.86 & \multirow[b]{2}{*}{$*$} & 0.003 & 0.719 & \multirow[b]{2}{*}{$* *$} \\
\hline & $\mathrm{b}$ & 0.106 & 0.025 & & 0.074 & 0.021 & & 0.145 & 0.005 & \\
\hline \multirow[b]{2}{*}{$\mathrm{EE}(\mathrm{g})$} & $\mathrm{a}$ & -10348 & 4206 & \multirow[b]{2}{*}{$* *$} & -53.6 & 35.3 & \multirow[b]{2}{*}{$*$} & -0.133 & 0.802 & \multirow[b]{2}{*}{$*$} \\
\hline & $\mathrm{b}$ & 0.514 & 0.087 & & 0.441 & 0.084 & & 0.017 & 0.006 & \\
\hline \multirow[b]{2}{*}{ Energy (kJ) } & $\mathrm{a}$ & -356 & 145 & \multirow[b]{2}{*}{$* *$} & -1.60 & 1.41 & \multirow[b]{2}{*}{$* *$} & -0.005 & 0.020 & \multirow[b]{2}{*}{$* *$} \\
\hline & $\mathrm{b}$ & 0.023 & 0.003 & & 0.019 & 0.003 & & 0.004 & 0.001 & \\
\hline
\end{tabular}

${ }^{1}$ Nutrients and energy in the MBnp $=\mathrm{a}+\mathrm{b} *$ MBnp.

${ }^{2}$ Nutrients and energy in the MGnp $=\mathrm{a}+\mathrm{b} *$ MGnp.

${ }^{3}$ Nutrients and energy in the Unp $=\mathrm{a}+\mathrm{b} *$ Unp.

${ }^{4} \mathrm{DM}$ - total amount of dry matter in each structure at the onset of pregnancy; Protein - total amount of protein in each structure at the onset of pregnancy; EE - total amount of ether extract in each structure at the onset of pregnancy; Energy - total amount of kilojoules in each structure at the onset of pregnancy.

$* \mathrm{P}<0.05 ; * * \mathrm{P}<0.01$. 
Analyses of the energy and protein profiles were performed on the serum samples. The metabolic energy profile was evaluated as follows: the non-esterified fatty acids (NEFA) were analyzed using the commercial kit from Randox ${ }^{\circledR}$ (FA115) based on Elphick (1968); ß-hydroxybutyrate was analyzed using the Randox ${ }^{\circledR}$ commercial kit (FA 1007) based on Williamson et al. (1962). The metabolic protein profile was evaluated through urea analyses by the urease method (Labtest Diagnóstica S.A., Brazil); total proteins by the biuret method (Labtest Diagnóstica S.A., Brazil); and albumin by the bromocresol green method (Labtest Diagnóstica S.A., Brazil). A Labquest ${ }^{\circledR}$ semi-automatic device for biochemical measurements was used for reading.

Additionally, hormone measurements were performed on the plasma samples using commercial kits for immunoenzymatic (EIA) determination of estrogen (Catalog \# ADI-901-174 - 17ß-Estradiol - Enzo Life Science), progesterone (Progesterone Test System 4825300 AccuBind $^{\circledR}$ - Monobind Inc.), and IGF-1 (Catalog \# ADI-900-150 - Enzo Life Science). Measurements were read using the Multiskam MS from Labsystems ${ }^{\circledR}$ version 8.0 for EIA measurements.

The animals were distributed among experimental treatments according to a completely randomized, $2 \times 2 \times 3$ factorial design (breeds $\times$ number of fetuses $\times$ days of pregnancy).

The total retention and relative daily nutrient retention rates of the maternal body, fetuses, empty uterus + fetal fluid, and mammary glands were analyzed as mixed models using the MIXED procedure of SAS (Statistical Analysis System, version 9.2). The models included random effects and the fixed effects of breed (Saanen or Oberhasli; 1 degree of freedom, DF), days of pregnancy (slaughter at 80,110 , or $140 ; 2 \mathrm{DF}$ ), number of fetuses (single or twin pregnancy; $1 \mathrm{DF}$ ), and their interactions. Distinct residual variances for the number of fetuses subclass and days of pregnancy were modeled using the GROUP option of the REPEATED command. When significant, means for the days of pregnancy were compared with Tukey's least significant difference test (PDIFF adjust=tukey option of the LSMEANS command). Significance was declared at $\mathrm{P}<0.05$.

The intake was analyzed in a factorial arrangement with repeated measures over time using animals chosen at random to be slaughtered at 140 days of pregnancy. Mixed models with fixed effects of breed (Saanen or Oberhasli; $1 \mathrm{DF}$ ), number of fetuses (single or twin pregnancy; $1 \mathrm{DF}$ ), days of intake (139 DF), their interactions, and the random effect were analyzed using the MIXED procedure in SAS
(Statistical Analysis System, version 9.2). The compoundsymmetry covariance structure was adopted as it reaches the lowest convergence criterion (BIC). Significance was declared at $\mathrm{P}<0.05$.

The blood metabolites were analyzed in a completely randomized design in a factorial arrangement with repeated measures over time. Mixed models with fixed effects of breed (Saanen or Oberhasli; 1 DF), number of fetuses (single or twin pregnancy; $1 \mathrm{DF}$ ), blood collection days $(1,35,50,65,80,95,110,125$, and $140 ; 8 \mathrm{DF})$, their interactions, and the random error were analyzed using the MIXED procedure in SAS (Statistical Analysis System, version 9.2). The compound-symmetry covariance structure was adopted as it reaches the lowest convergence criterion (BIC). Significance was declared at $\mathrm{P}<0.05$.

\section{Results}

There was no effect of breed on the calculations used to estimate empty body weight, maternal body, and mammary glands in non-pregnant goats, so the same equation was used for both breeds (Eqs. [2], [3] and [4]).

EBWnp $=-7.77+1.03 * B W n p, \mathrm{SEM}=5.06, \mathrm{P}<0.01, \mathrm{r}^{2}=0.97$
$M B n p=0.302+0.981 * E B W n p, \mathrm{SEM}=0.075, \mathrm{P}<0.01, \mathrm{r}^{2}=0.99$
$M G n p=-98.60+9.70 * M B n p, \mathrm{SEM}=143, \mathrm{P}<0.05, \mathrm{r}^{2}=0.44$

in which EBWnp = empty body weight at the beginning of pregnancy $(\mathrm{kg})$; BWnp = body weight at the beginning of pregnancy $(\mathrm{kg}) ; \mathrm{MBnp}=$ maternal body at the beginning of pregnancy $(\mathrm{kg})$; and MGnp = mammary glands at the beginning of pregnancy $(\mathrm{g})$.

The initial weight of the uterus (Unp) was estimated by difference, as described below (Eq. [5]):

$$
U n p=E B W n p-M B n p-M G n p
$$

The estimates of DM, EE, CP and energy from the maternal body, mammary glands and uterus at the beginning of pregnancy were different among breeds and were calculated from the equations (intercepts and slopes) shown in Table 2.

No effect of breed was observed on DM and protein intake. However, there was an effect of the number of fetuses on DM intake $\left(\mathrm{g} \mathrm{d}^{-1}\right)$. In the goats with twin pregnancies, DM intake decreased at an increasing rate after the first third of the duration of pregnancy (quadratic, $\mathrm{P}<0.05$; Figure 1). On the other hand, females with single pregnancies showed a constant DM intakes throughout pregnancy $(1160 \pm 131 \mathrm{~g}$ $\left.\mathrm{DM} \mathrm{d}^{-1}\right)$. There was no effect of the number of fetuses on $\mathrm{CP}$ intake, which decreased at an increasing rate (quadratic, $\mathrm{P}<0.05$ ) from the first third of pregnancy on (Figure 1). The variation in $\mathrm{DM}$ and $\mathrm{CP}$ intake over the gestation period 
was similar regardless of the unit in which the intake was expressed $\left(\mathrm{g} \mathrm{d}^{-1} ; \mathrm{g} \mathrm{kg}^{-1}\right.$ body weight $\mathrm{d}^{-1} ; \mathrm{g} \mathrm{kg}^{-1}$ metabolic weight $\left.\left(\mathrm{kg}^{0.75}\right) \mathrm{d}^{-1}\right)$.

Overall, the variation in maternal body (MB) weight was $4.65 \mathrm{~kg}$ on average and was not affected by the number of fetuses. However, this variation in weight changed as pregnancy advanced. Up to 80 days, the rate of gain was $2.70 \pm 0.23 \mathrm{~g} \mathrm{~kg}^{-1} \mathrm{MB} \mathrm{d}^{-1}$, but from 80 days on, MB weight gain dropped to $1.11 \pm 0.33 \mathrm{~g} \mathrm{~kg}^{-1} \mathrm{MB} \mathrm{d}^{-1}$ until 110 days into pregnancy, when it decreased to $0.02 \pm 0.34 \mathrm{~g} \mathrm{~kg}^{-1} \mathrm{MB} \mathrm{d}^{-1}$ until 140 days $(\mathrm{P}<0.01)$. Oberhasli goats showed a higher weight gain than the Saanen goats: $1.70 \pm 0.26$ vs. $0.86 \pm 0.22$, respectively.

The total retention and the relative daily nutrient retention rate in the maternal body were not affected by breed and number of fetuses (Table 3). The total retention of nutrients in the maternal body was higher until 110 days of pregnancy, whereas at 140 days of pregnancy, the total amount of nutrients decreased $(\mathrm{P}<0.05$; Table 3$)$. The relative retention rates of $\mathrm{DM}$ and protein $\left(\mathrm{g} \mathrm{kg}^{-1} \mathrm{MB} \mathrm{d}^{-1}\right)$ in the maternal body declined as pregnancy advanced, while the relative daily retention rates of $\mathrm{EE}\left(\mathrm{g} \mathrm{kg}^{-1} \mathrm{MB} \mathrm{d}^{-1}\right)$ and energy $\left(\mathrm{J} \mathrm{kg}^{-1} \mathrm{MB} \mathrm{d}^{-1}\right)$ only decreased at 140 days of pregnancy $(\mathrm{P}<0.05$; Table 3$)$.

There was no effect of breed on total retention and relative daily nutrient retention rate on the fetuses $(\mathrm{P}>0.05)$, except for fetal mass, for which the Oberhasli fetuses were $13 \%$ larger than the Saanen $(\mathrm{P}<0.05$; Table 4$)$. The total weight of the fetuses as well as the total retention of nutrients in them was higher $(\mathrm{P}<0.05)$ in twin pregnancies. However,

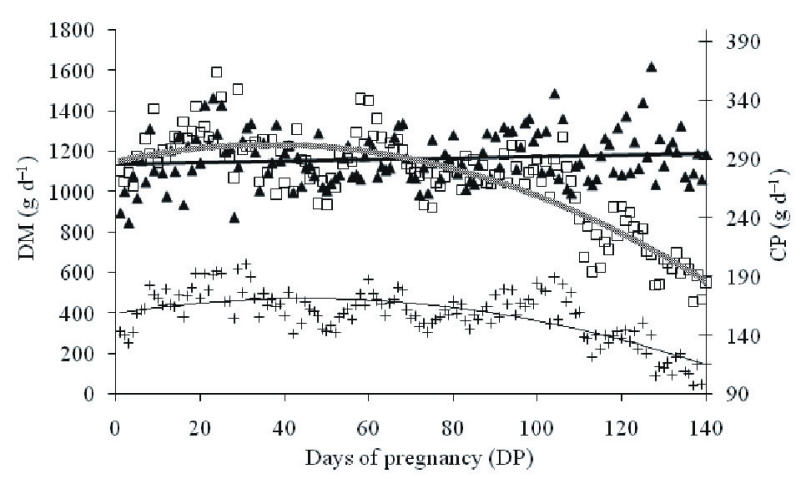

Equation to estimate the average daily DM intake in animals with a twin pregnancy: DMI $\left(\mathrm{g} \mathrm{d}^{-1}\right)=1149.2 \pm 42.84+4.61 \pm 2.60 \mathrm{DP}-0.063 \pm 0.04 \mathrm{DP}^{2} ; \mathrm{SEM}=123.8 ; \mathrm{R}^{2}=0.72$.

Equation to estimate the average daily CP intake $\left(\mathrm{g} \mathrm{d}^{-1}\right)=158.51 \pm 4.92+$ $0.548 \pm 0.15 \mathrm{DP}-0.006 \pm 0.001 \mathrm{DP}^{2} ; \mathrm{SEM}=65.12 ; \mathrm{R}^{2}=0.53$.

Breed had no effect on $(\mathrm{P}>0.05) \mathrm{DM}$ and $\mathrm{CP}$ intake.

Figure 1 - Dry matter (DM; 1 fetus $-\boldsymbol{\Delta}$ and 2 fetuses $-\square)$ and crude protein $(\mathrm{CP} ;-+)$ intake in dairy goats throughout pregnancy. the relative daily retention rates of nutrients and energy were the same for both single and twin pregnancies.

The total retention of nutrients in the fetus was higher at 140 days of pregnancy, and fetal growth between 80 and 140 days of pregnancy corresponded to $92.6 \%$ of the weight of the fetuses at 140 days of pregnancy (Table 4). The relative daily retention rates of $\mathrm{EE}$ and energy in the fetuses were higher $(\mathrm{P}<0.05)$ at 110 days of pregnancy (Table 4$)$.

The greatest retentions of uterine mass and fetal fluid, $\mathrm{DM}$, protein and energy in the uterus and fetal fluid were observed at 110 and 140 days of pregnancy $(\mathrm{P}<0.01)$ and were higher in Oberhasli goats $(\mathrm{P}<0.05)$. The highest relative daily retention rates of weight and these nutrients in the uterus and fetal fluid were at 80 days of pregnancy $(\mathrm{P}<0.05$; Table 5) and were also higher for the Oberhasli goats $(\mathrm{P}<0.05)$. In addition, the twin pregnancies displayed higher retentions of uterine mass and fetal fluid, DM and protein $(\mathrm{P}<0.05)$. However, only the retention rates of uterine mass and fetal fluid were higher in the twin pregnancies $(\mathrm{P}<0.05)$.

Oberhasli goats had a higher retention of fat (EE) in the mammary glands $(\mathrm{P}<0.05$; Table 6$)$, and goats with a twin pregnancy showed greater retention of fat and energy in the mammary glands $(\mathrm{P}<0.05)$. The total retention of nutrients in the mammary glands increased as pregnancy advanced $(\mathrm{P}<0.05)$ but at a relatively constant daily rate (Table 6).

Up to the gestational age of 80 days, the products of gestation (fetuses, mammary glands, uterus, and fetal fluids) amounted to 209.1 g of retained protein (Tables 4, 5, and 6). After 80 days, protein retention increased exponentially until the end of pregnancy, with elevations of $262 \%$ and $522 \%$ at 110 and 140 days of gestation, respectively, which reflect the differences found in the protein retention rate in the maternal body as pregnancy progressed. The maternal body mobilized approximately $1,175 \mathrm{~g}$ of protein while it deposited $1,090 \mathrm{~g}$ of protein in the products of gestation. In contrast, the maternal body mobilized $4,436 \mathrm{~g}$ of fat, whereas that which accumulated in the products of gestation totaled $353 \mathrm{~g}$.

The total amount of blood collected at the moment of slaughter increased linearly throughout pregnancy $(\mathrm{P}<0.01)$, showing an elevation of $34 \%$ at 140 days of gestation compared to that collected from non-pregnant females.

The highest levels of ß-hydroxybutyrate were observed from 110 days of pregnancy (Figure 2), and there was no effect of breed or type of pregnancy $(\mathrm{P}>0.05)$ on the serum levels of this metabolite. Likewise, the highest NEFA serum levels were observed in the last 30 days of gestation (Figures 4 and 5). However, Oberhasli goats showed higher $(\mathrm{P}<0.01)$ serum NEFA concentrations at 125 days compared 

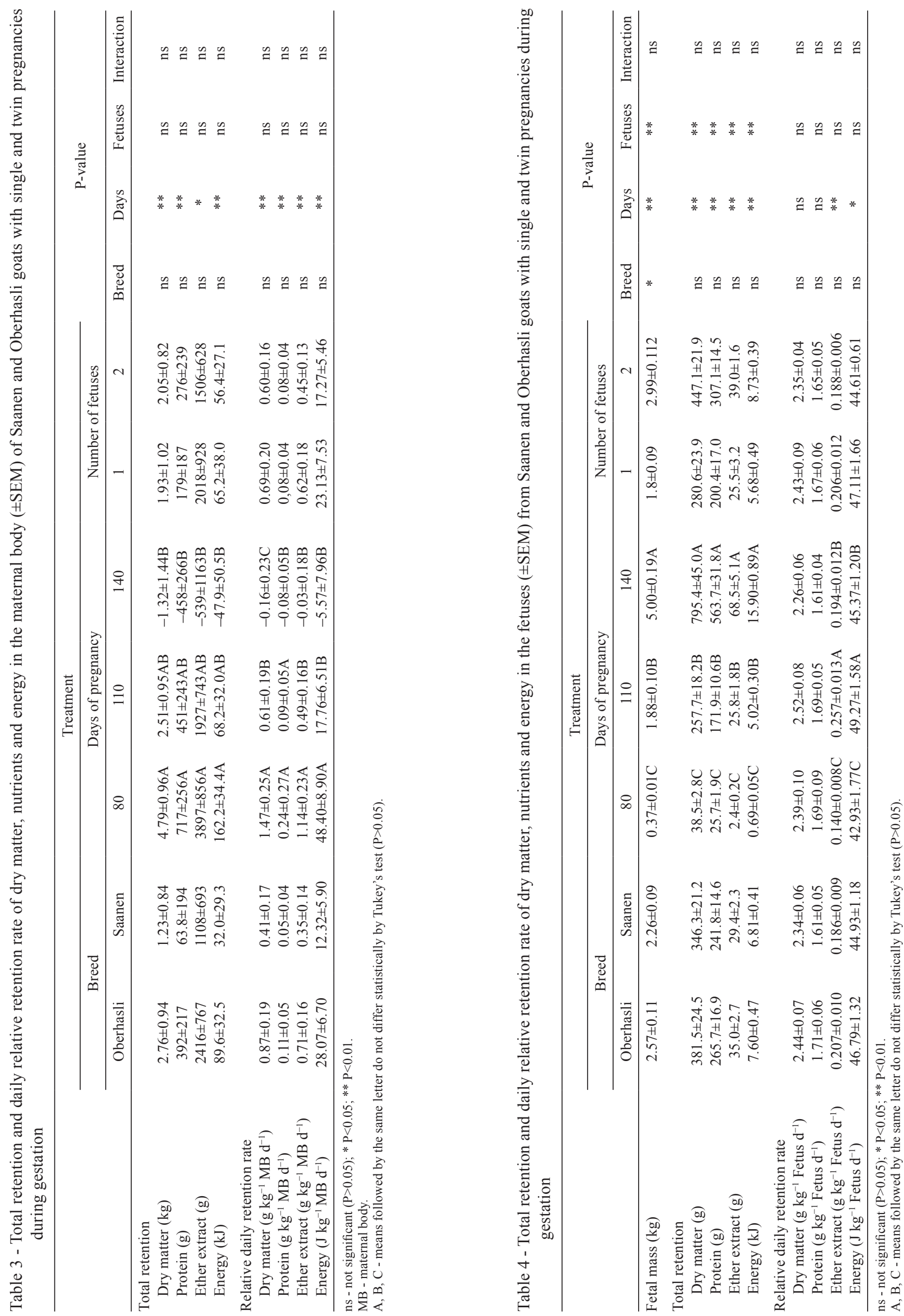

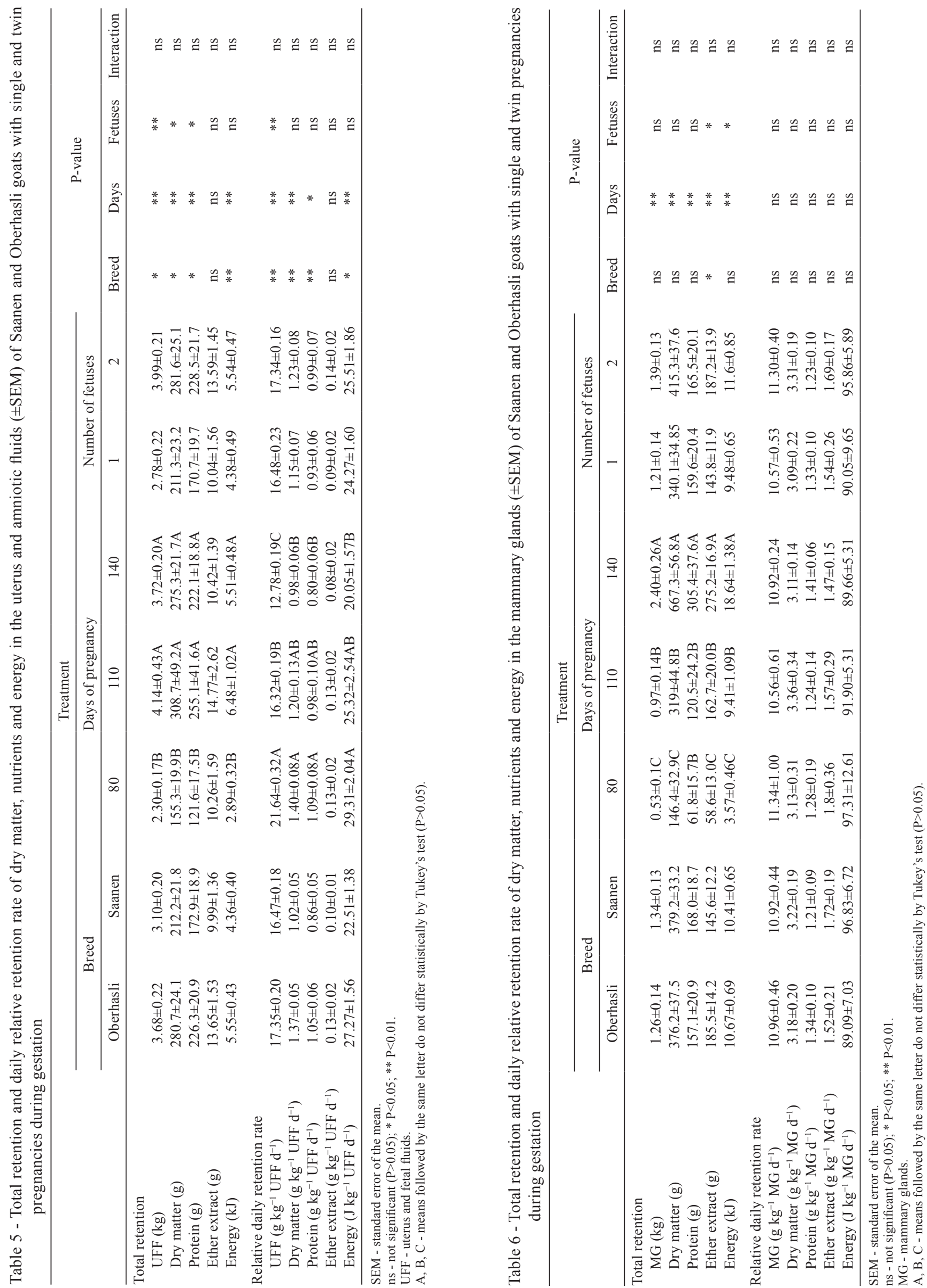

R. Bras. Zootec., 44(3):92-102, 2015 
with the concentrations in Saanen goats (Figure 3). Moreover, animals with twin pregnancies showed higher concentrations of NEFA at 110 days compared with animals with single pregnancies $(\mathrm{P}<0.05$; Figure 4$)$.

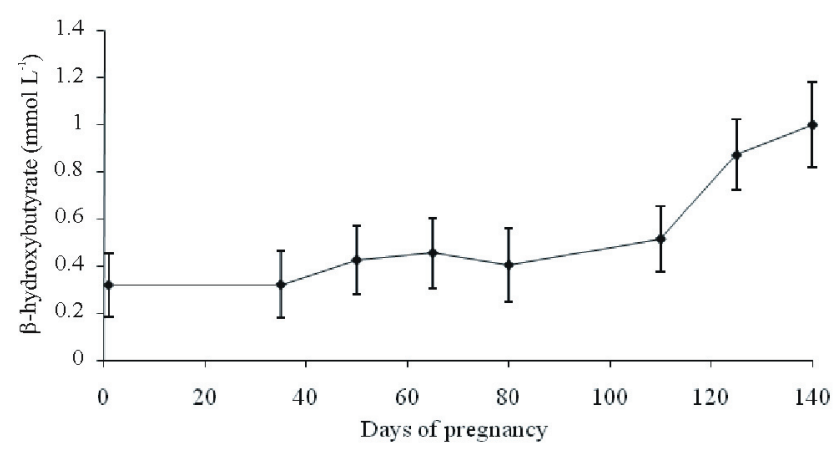

There was no effect of type of pregnancy or breed $(\mathrm{P}>0.05)$ on the levels of ß-hydroxybutyrate.

Figure 2 - $\beta$-hydroxybutyrate serum concentrations in goats at different stages of pregnancy $( \pm \mathrm{SEM})$.

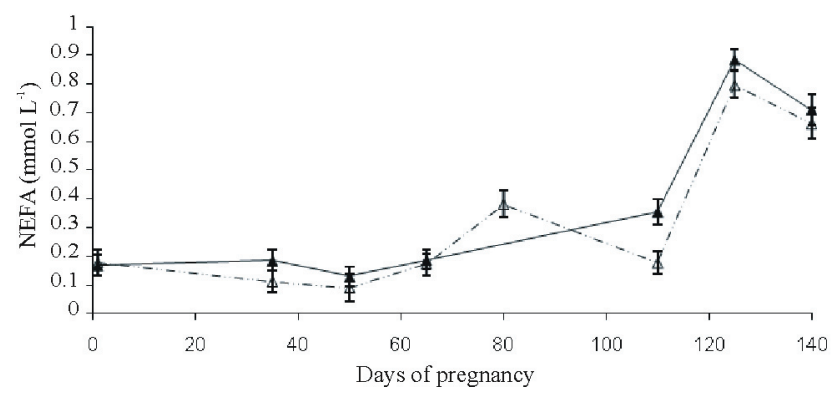

Breed $\times$ days interaction $(\mathrm{P}<0.01)$.

Figure 3 - Serum concentrations of non-esterified fatty acids (NEFA) in Oberhasli $\left(-\mathbf{\Delta}^{-}\right)$and Saanen $(-)$goats at different stages of pregnancy $( \pm \mathrm{SEM})$.

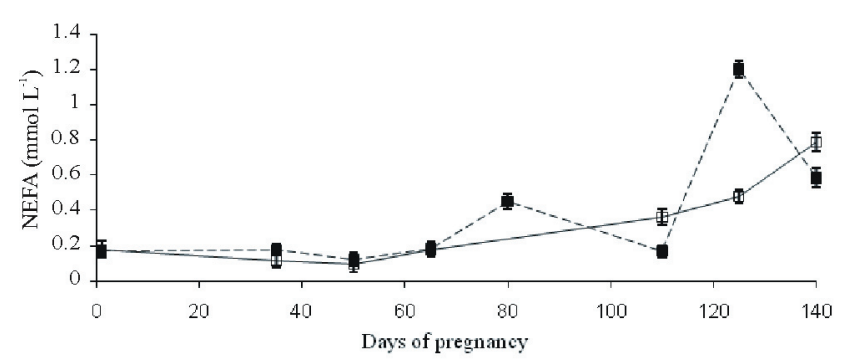

Fetuses $\times$ days interaction $(\mathrm{P}<0.05)$.

Figure 4 - Serum concentrations of non-esterified fatty acids (NEFA) in goats with single $(\square)$ and twin $(--)$ pregnancies at different stages of pregnancy $( \pm$ SEM).
The serum urea levels decreased $(\mathrm{P}<0.05)$ from 80 days of pregnancy (Figure 5) and were not affected by the number of fetuses or breed. Serum total protein and albumin (Figure 5) levels decreased after 135 days of pregnancy and were not affected by the type of pregnancy or breed.

The plasma 17ß-estradiol levels increased with the advance of pregnancy $(\mathrm{P}<0.05$; Figure 6$)$. On the other hand, plasma IGF-1 levels were highest between 60 and 80 days of pregnancy (Figure 7), and there was no effect of breed or type of pregnancy.

Plasma progesterone concentrations were higher $(\mathrm{P}<0.01)$ in the goats with twin pregnancies, averaging $17.08 \pm 1.01 \mathrm{pg} \mathrm{mL}^{-1}$, while single pregnancy goats showed an average of $13 \pm 1.08 \mathrm{pg} \mathrm{mL}^{-1}$. Plasma insulin levels over the total gestation period remained constant, at approximately $10.43 \pm 0.36 \mu \mathrm{IU} \mathrm{mL}^{-1}$.

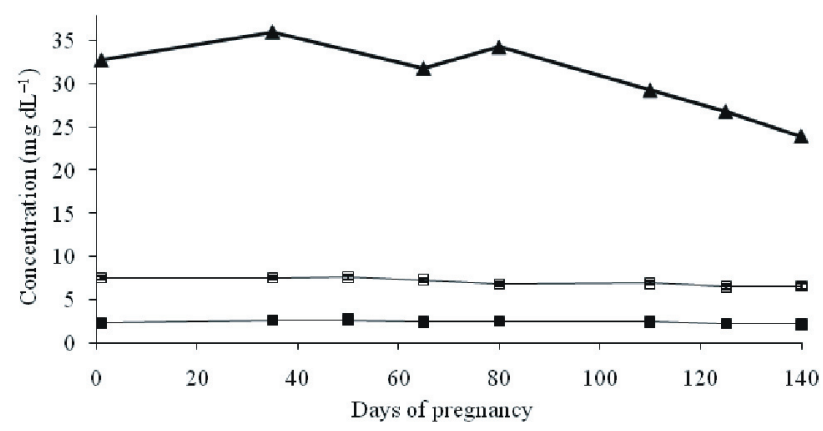

There was no effect of number of fetuses or breed $(\mathrm{P}>0.05)$ on the levels of this metabolite.

Figure 5 - Serum concentrations of urea $(\rightarrow)$, total proteins $(\square)$, and albumin $(--)$ in goats at different stages of pregnancy $( \pm$ SEM).

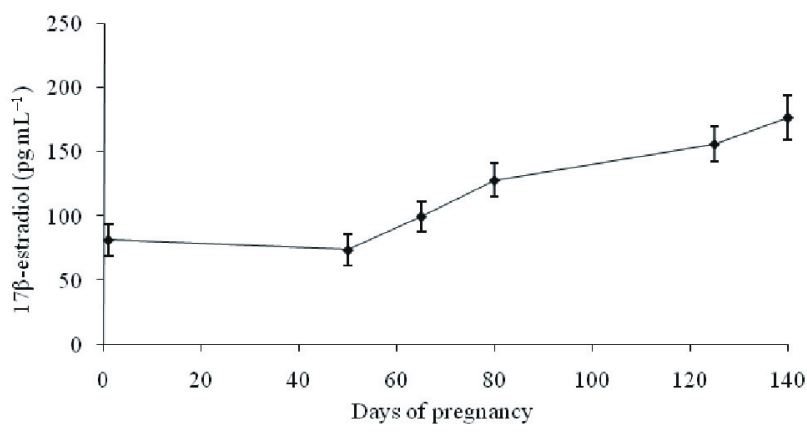

There was no effect of type of pregnancy or breed $(\mathrm{P}>0.05)$ on $17 ß$-estradiol levels.

Figure 6 - Plasma 17ß-estradiol levels in goats at different stages of pregnancy $( \pm \mathrm{SEM})$. 


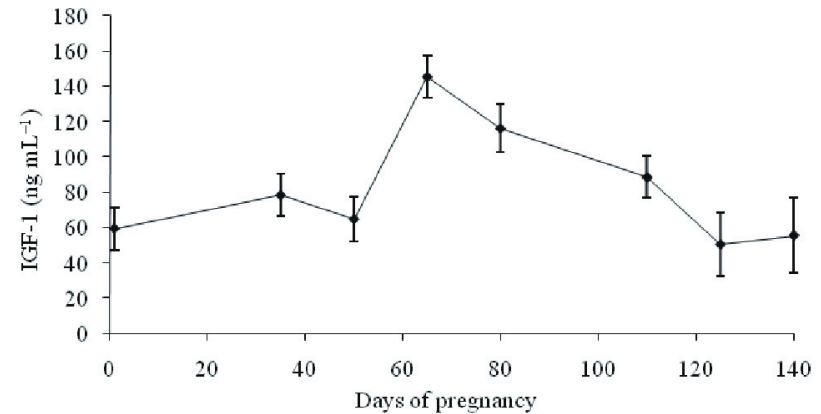

There was no effect of type of pregnancy or breed on plasma IGF-1 concentrations $(\mathrm{P}>0.05)$.

Figure 7 - Plasma IGF-1 concentrations in goats at different stages of pregnancy $( \pm \mathrm{SEM})$.

\section{Discussion}

Our study sought to evaluate the effect of the type of pregnancy in different breeds of dairy goats throughout gestation. One of the most important findings was that the major changes in maternal metabolism as well as in nutrient retention during pregnancy were caused by the progression of pregnancy, regardless of the number of fetuses.

The total weight of the fetuses in a twin pregnancy was $66 \%$ higher than in a single pregnancy, which likely caused a compression of the rumen and lower DM intake in goats with twin pregnancies. The reduction of intake in pregnant females may not only be associated with the physical limitation but also with an increase in the levels of plasma estrogen released from the placenta (Grummer, 1990; Forbes, 2007). Additionally, it has been reported that lower estrogen:progesterone ratios interfere with intake (Grummer, 1995), which may also be related to the lower DM intake observed as the cows pregnant with twins showed a lower ratio of these hormones.

Although we observed a decrease in dry matter intake by animals with twin pregnancies at the end of gestation, this was not reflected in the mobilization of nutrients from the maternal body. This efficiency in maternal metabolism during twin pregnancy may be related to the increased digestibility of nutrients that occurs as reported by Macedo Junior et al. (2012). The energy expenditure associated with digestion can be influenced by factors such as the type of food and intake level (Lima et al., 2008; Labussière et al., 2011), and this may be directly reflected in the maintenance requirements. Thus, the goats with twin pregnancies might have reduced their maintenance requirements as they showed lower DM intake, but even with a lower intake, the input of nutrients to the goat was not impaired. Nevertheless, more studies related to changes in maintenance requirements during pregnancy are needed.

The order in which tissues are deposited in the body during growth starts with the nervous tissue followed by the bone, muscular, and, lastly, adipose tissues (Lawrence et al., 2012). In our study, this theory is supported because the proportion of protein deposited in the fetus during pregnancy was greater than fat. In addition, the protein in the maternal body was stored in larger quantities at the beginning of pregnancy (until 80 days) and began to decline with its advance due to the transfer of this nutrient to sustain protein deposition in the fetus(es).

The protein mobilized in the maternal body during pregnancy is not only intended for fetal development but is also the primary nutrient supplied to the uterine tissues. Because the quantity of protein is limited, the uterus cannot sustain normal fetal growth (Bell, 1995), and this was one of the causes of the high amounts of protein mobilized from the maternal body, especially from 110 to 140 days of pregnancy. Additionally, the lower crude protein intake observed during the final third of pregnancy period led to a decrease in serum urea levels. As a consequence, urea recycling via the ruminal epithelium and saliva may be more efficient and improve the uptake of nitrogen to the ruminal microorganisms (Brun-Bellut, 1997; Marini and Van Amburgh, 2003). This demonstrates that protein retention in the products of gestation cannot be achieved solely through the feed ingested by the goat; we observed that protein deposition in the products of gestation was $93 \%$ of the total that was mobilized in the maternal body.

The drop in the levels of serum total proteins and albumin with the advance of pregnancy may be related to the higher protein and energy requirements for gestation (Balikci et al., 2007), given that hepatic gluconeogenesis in ruminants is primarily performed with gluconeogenic amino acids (Kozloski et al., 2009). However, another aspect to be considered is that the reduction in the serum concentration of these metabolites may be related to the increased maternal blood volume during gestation (Azab and Abdel-Maksoud, 1999), which, in turn, is caused by an increase in serum estrogen levels (Dickson et al., 1969; Bell, 1975; Ford, 1995). An increase in blood volume was observed in this study, and although the amount of blood collected at slaughter does not directly represent the total amount of circulating blood, it can indicate an increase.

In contrast with protein, only $8 \%$ of the total amount of fat mobilized from the maternal body was proportionally retained in the products of gestation. Although the loss of fat due to the use of the body reserves is $80 \%$ (AAC-SCA, 1990), it is believed that the remaining energy mobilized 
from the body reserves fulfills the maintenance energy requirements of the goat. As previously stated, we observed that this mobilization is concentrated in the final third of pregnancy (Khan and Lundri, 2002), which can be verified by the increasing levels of serum NEFA and ß-hydroxybutyrate during this phase.

Fetal growth between 80 and 140 days of pregnancy corresponded to $92.6 \%$ of the total weight of the fetus, which corroborates studies conducted by Ferrel (1992) and Lima (2011). The relative daily retention rates of DM and protein indicate that the composition of gain, proportional to the size of the fetuses, is the same throughout gestation. Unlike the fetuses, the increased development of the uterus and fetal fluid occurs over the first two thirds of pregnancy irrespective of the number of fetuses. This may be related to the higher plasma concentrations of the IGF-1 hormone, which is directly related to muscle tissue growth. In support of this hypothesis, we observed that the highest concentrations of IGF-1 occurred between 65 and 80 days of pregnancy, which was the phase when the uterus showed the highest daily growth rate.

The fetuses from the Oberhasli goats were larger, which could be due to the higher daily retention rates in the uterus and fetal fluid, whose masses are proportional to the size of the fetus (Bell et al., 2005). These relationships between the weight of the uterus and fetal fluid and the size of the fetus seem to be related to bone growth, since we did not find greater deposition of protein and fat in the Oberhasli goat fetuses. Comparative information for these breeds is still scarce, and further studies are needed to find differences in their production efficiency.

The results of the present study are of great importance to decision-making regarding feeding management for pregnant goats. Given that the mobilization of fat and protein in the maternal body as well as the deposition of the products of gestation are not affected by twin pregnancy, we emphasize the importance of maintaining the nutritional status of pregnant goats to prevent body mobilizations higher than what can be supported. In addition, goats may have triplet and quadruplet births, so more studies are needed to evaluate the effects of the gestation of three or four fetuses on maternal metabolism.

\section{Conclusions}

The maternal metabolism during pregnancy does vary according to the type of pregnancy (single or twin).

Changes in the metabolism of protein and energy occur mainly with the advance of pregnancy such that goats use their body fat reserves to meet their nutritional requirements of maintenance and gestation during the final third of pregnancy.

\section{Acknowledgments}

The authors thank the São Paulo Research Foundation (FAPESP grants \#2010/04565-4, 2007/58239-8 and 2006/60480-2) for the financial support.

\section{References}

AAC-SCA - Australian Agricultural Council. Standing Committee on Agriculture: Ruminant Subcommittee. 1990. Feeding standards for Australian livestock: Ruminants. CSIRO Publications, East Melbourne.

AOAC - Association of Official Analytical Chemistry. 1990. Official methods of analysis. 15th ed. AOAC International, Arlington, VA.

Amoah, E. A.; Gelaye, S.; Guthrie, P. and Rexroad Jr., C. E. 1996. Breeding season and aspects of reproduction of female goats. Journal of Animal Science 74:723-728.

ARC - Agricultural Research Council. 1980. The nutrient requirements of ruminant livestock. Commonwealth Agricultural Bureaux, Slough, UK.

Azab, M. E. and Abdel-Maksoud, H. A. 1999. Changes in some hematological and biochemical parameters during prepartum and postpartum periods in female Baladi goats. Small Ruminant Research 34:77-85.

Balikci, E.; Yildiz, A. and Gürdoğan, F. 2007. Blood metabolite concentrations during pregnancy and postpartum in Akkaraman ewes. Small Ruminant Research 67:247-251

Bauman, D. E. and Currie, W. B. 1980. Partitioning of nutrients during pregnancy and lactation: A review of mechanisms involving homeostasis and homeorhesis. Journal of Dairy Science 63:1514-1529.

Bell, A. W. 1995. Regulation of organic nutrient metabolism during transition from late pregnancy to early lactation. Journal of Animal Science 73:2804-2819.

Bell, A. W.; Greenwood, P. L. and Ehrhardt, R. A. 2005. Regulation of metabolism and growth during prenatal life. p.3-34. In: Biology of metabolism in growing animals. v.3. Burrin, D. G. and Mersmann, H. J., eds. Elsevier, Sydney.

Bell, C. 1975. Control of uterine blood flow in pregnancy. Obstetrical and Gynecological Survey 30:359-360.

Boichard, D.; Bouloc, N.; Ricordeau, G.; Piacere, A. and Barillet, F. 1989. Genetic parameters for first lactation dairy traits in the Alpine and Saanen goat breeds. Genetics Selection Evolution 21:205-215.

Bonnet, M.; Gourdou, I.; Leroux, C.; Chilliard, Y. and Djiane, J. 2002. Leptin expression in the ovine mammary gland: putative sequential involvement of adipose, epithelial, and myoepithelial cells during pregnancy and lactation. Journal of Animal Science 80:723-728.

Brun-Bellut, J. 1997. Urea recycling in the rumen of dairy goats: effects of physiological stage and composition of intake. Small Ruminant Research 23:83-90.

Conway, M. L. T.; Blacksham, J. K and Daniel, R. C. W. 1996. The effects of agonistic behaviour and nutritional stress on both the success of pregnancy and various plasma constituents in Angora goats. Applied Animal Behaviour Science 48:1-13.

Dickson, W. M.; Bosc, M. J. and Locattelli, A. 1969. Effect of estrogen and progesterone on uterine blood flow of castrate sows. American Journal of Physiology 217:1431-1434. 
Duarte, M. S.; Gionbelli, M. P.; Paulino, P. V. R.; Serão, N. V. L.; Martins, T. S.; Tótaro, P. I. S.; Neves, C. A.; Valadares Filho, S. C.; Dodson, M. V.; Zhu, M. and Du, M. 2013. Effects of maternal nutrition on development of gastrointestinal tract of bovine fetus at different stages of gestation. Livestock Science 153:60-65.

Elphick, M. C. 1968. Modified colorimetric ultramicro method for estimating Nefa in serum. Journal of Clinical Pathology 21:567-570.

Etheridge, R. D.; Pesti, G. M. and Foster, E. H. 1998. A comparison of nitrogen values obtained utilizing the Kjeldahl nitrogen and Dumas combustion methodologies (Leco CNS 2000) on samples typical of an animal nutrition analytical laboratory. Animal Feed Science and Technology 73:21-28.

Ferrel, C. L. 1992. Nutrient requirements, other factors affect fetal growth. Feedstuffs 17:18-41.

Forbes, J. M. 2007. Voluntary food intake and diet selection in farm animals. CAB International, Wallingford, UK.

Ford, S. P. 1995. Control of blood flow to the gravid uterus of domestic livestock species. Journal of Animal Science 73:1852-1860.

Grummer, R. R.; Bertics, S. J.; Lacount, D. W.; Snow, J. A.; Dentine, M. R. and Stauffacher, R. H. 1990. Estrogen induction of fatty liver in dairy cattle. Journal of Dairy Science 73:1537-1543.

Grummer, R. R. 1995. Impact of changes in organic nutrient metabolism on feeding the transition dairy cow. Journal of Dairy Science 73:2820-2833.

Khan, J. R. and Lundri, R. S. 2002. Hormonal profiles during periparturient period in single and twin fetus bearing goats. AsianAustralasian Journal of Animal Sciences 15:346-351.

Kozloski, G. V.; Lima, L. D.; Chiesa, A. P. R.; Oliveira, L.; Fiorentini, G. and Härter, C. J. 2009. Fluxo portal e visceral líquido de metabólitos em ovinos alimentados com feno de capim-arroz cortado com diferentes idades de rebrota. Revista Brasileira de Zootecnia 38:1114-1120.

Labussière, E.; van Milgen, J.; Lange, C. F. M. and Noblet, J. 2011. Maintenance energy requirements of growing pigs and calves are influenced by feeding level. The Journal of Nutrition 141:1855-1861.

Lawrence, T.; Fowler, V. and Novakofski, J. 2012. Growth of farm animals. 3rd ed. CABI, Oxfordshire, UK.

Lima, L. D.; Kozloski, G. V.; Sanchez, L. M. B.; Chiesa, A. P. R.; Härter, C. J.; Fiorentini, G.; Oliveira, L. and Cadorin Jr., R. L. 2008. Effect of harvesting period on the nutritive value of rice grass (Echinochloa sp.) hay given as sole diet to lambs. Small Ruminant Research 75:217-225.
Lima, L. D. 2011. Desenvolvimento e composição química do útero gravídeo, da glândula mamária e as mudanças corporais em cabras durante a gestação. Tese (D.Sc.). Universidade Estadual Paulista, Jaboticabal.

Lofgreen, G. P. and Garrett, W. N. 1968. A system for expressing net energy requirements and feed values for growing and finishing beef cattle. Journal of Animal Science 27:793-806.

Macedo Junior, G. L.; Benevides, Y. I.; Campos, W. E.; Borges, I.; Rodriguez, N. M. and Ferreira, D. A. 2012. Nutrient intake and digestibility and ruminal rate passage in pregnant ewes. Ciência Animal Brasileira13:429-439.

Macciotta, N. P. P.; Dimauro, C.; Rassu, S. P. G.; Steri, R. and Pulina, G. 2011. The mathematical description of lactation curves in dairy cattle. Italian Journal of Animal Science 10:e51: 213-223.

NRC - National Research Coucil. 2007. Nutrients requirements of small ruminant: sheep, goats, cervids and New World camelids. National Academy, Washington, DC.

Marini, J. C. and Van Amburgh M. E. 2003. Nitrogen metabolism and recycling in Holstein heifers. Journal of Animal Science 81:545-552.

Prezotto, L. D.; Camacho, L. E.; Lemley, C. O.; Doscher, F. E.; Caton, J. S.; Vonnahme, K. A. and Swanson, K. C. 2013. Effects of nutrient restriction on liver and small intestine energy use in pregnant beef cows. p.463-464. In: Energy and protein metabolism and nutrition in sustainable animal production. Oltjen, J. W.; Kebreab, E. and Lapierre, H., Eds. Sacramento, CA, USA.

Ritar, A. J.; Maxwell, W. C. W. and Salamon, S. 1984. Ovulation and LH secretion in the goat after intravaginal progestagen sponge PMSG treatment. The Journal of the Society for Reproduction and Fertility 72:559-563.

Robertson, J. B. and Van Soest, P. J. 1981. The detergent system of analysis and its application to human foods. In: The analysis of dietary fiber in food. James, W. P. T. and Theander, O., eds. Marcel Dekker, New York.

Silanikove, N. 2000. The physiological basis of adaptation in goats to harsh environments. Small Ruminant Research 35:181-193.

Valadares Filho, S. C.; Rocha Junior, V. R. and Cappelle, E. R. 2002. Tabelas brasileiras de composição de alimentos para bovinos. Viçosa, MG, Brasil.

Westhuysen, J. M. van der. 1979. The control of ovarian function in cycling and anoestrus angora goats. Agroanimalia, Pretoria 11:23-25.

Williamson, D. H.; Mellanby, J. and Krebs, H. A. 1962. Enzymatic determination of $\mathrm{D}(-)-\beta$-hydroxybutyric acid and acetoacetic acid in blood. Biochemical Journal 82:90-96. 